WIDER Working Paper 2016/81

\title{
The history and politics of energy transitions
}

Comparing contested views and finding common ground

Benjamin K. Sovacool *

June 2016 
Abstract: According to some definitions, an energy transition refers to the time that elapses between the introduction of a new primary energy source, or prime mover, and its rise to claiming a substantial share of the overall market. According to one academic view, energy transitions take an incredibly long time to occur. Another view argues the opposite. It suggests that there have been many transitions at varying scales that have occurred quite quickly - that is, between a few years and a decade or so, or within a single generation. This paper holds that both sides are partly right, and partly wrong. After presenting evidence in support of either thesis, it elucidates four lessons for energy analysts and policy makers.

Keywords: energy transitions, energy pathways, transition pathways, energy security JEL classification: N7, P28, P48, Q47

\footnotetext{
* Professor of Business and Social Sciences and Director of the Center for Energy Technologies, Aarhus University, Herning, Denmark and Professor of Energy Policy, Science Policy Research Unit (SPRU), School of Business, Management, and Economics, University of Sussex, United Kingdom, BenjaminSo@hih.au.dk
}

This study has been prepared within the UNU-WIDER project on 'The Political Economy of Clean Energy Transitions'.

Copyright (C) UNU-WIDER 2016

Information and requests: publications@wider.unu.edu

ISSN 1798-7237 ISBN 978-92-9256-124-6

Typescript prepared by Leslie O’Brien.

The United Nations University World Institute for Development Economics Research provides economic analysis and policy advice with the aim of promoting sustainable and equitable development. The Institute began operations in 1985 in Helsinki, Finland, as the first research and training centre of the United Nations University. Today it is a unique blend of think tank, research institute, and UN agency — providing a range of services from policy advice to governments as well as freely available original research.

The Institute is funded through income from an endowment fund with additional contributions to its work programme from Denmark, Finland, Sweden, and the United Kingdom.

Katajanokanlaituri 6 B, 00160 Helsinki, Finland

The views expressed in this paper are those of the author(s), and do not necessarily reflect the views of the Institute or the United Nations University, nor the programme/project donors. 
Transitioning away from our current global energy system is of paramount importance (Riahi et al. 2012). As Grubler (2012: 8) has compellingly written, "the need for the "next" energy transition is widely apparent as current energy systems are simply unsustainable on all accounts of social, economic, and environmental criteria'. Miller et al. (2012: 136) add that 'The future of energy systems is one of the central policy challenges facing industrial countries'. Unfortunately, however, neither private markets nor government agencies seem likely to spur a transition on their own (Fri and Savitz 2014). Moreover, shifts to newer, cleaner energy systems such as sources of renewable electricity (Painuly 2001; Sovacool 2009) or electric vehicles (Sovacool and Hirsh 2009; Nielsen et al. 2015) often require significant shifts not only in technology, but also in political regulations, tariffs, and pricing regimes, and the behaviour of users and adopters.

Thus, the speed at which a transition can take place-its timing, or temporal dynamics-is a critical element of consideration (Sovacool 2016). According to the International Energy Agency (2012: 3), for example, if 'action to reduce CO2 emissions is not taken before 2017, all the allowable CO2 emissions would be locked-in by energy infrastructure existing at that time'. In other words, if a transition does not occur quickly, or soon, it may be too late. Giddens (2009) went so far as to call this the 'climate paradox', the fact that by the time humanity may come to realize fully how much they need to shift to low-carbon forms of energy, they will have already passed the point of no return.

The notion of 'energy transitions' sits at the heart of this polemical discussion. O'Connor (2010) once defined an energy transition as 'a particularly significant set of changes to the patterns of energy use in a society, potentially affecting resources, carriers, converters, and services'. In other words, to those subscribing to this definition, an energy transition refers to the time that elapses between the introduction of a new primary energy source, or prime mover, and its rise to claiming a substantial share of the overall market. According to one view, energy transitions take an incredibly long time to occur. As the geographer Vaclav Smil (2010a: 141-2) writes, 'all energy transitions have one thing in common: They are prolonged affairs that take decades to accomplish, and the greater the scale of prevailing uses and conversions, the longer the substitutions will take'. Fast transitions, when they occur at all, are anomalies, limited to countries with very small populations or unique contextual circumstances that can hardly be replicated elsewhere.

Another view argues the opposite. Broadening the discussion beyond simply national sources of energy supply and substantial shifts of their composition, it suggests that there have been many transitions - at varying scales, involving different things including fuels, services, and end-use devices - that have occurred quite quickly. That is, between a few years and a decade or so, or within a single generation. At smaller scales, the adoption of cookstoves, air conditioners, and flex-fuel vehicles are excellent examples. At the state or national scale, almost complete transitions to oil in Kuwait, natural gas in the Netherlands, and nuclear power in France took only a decade, roughly, to occur. Indeed, the second part of this paper presents ten case studies of energy transitions that, in aggregate, affected almost one billion people and needed only 1 to 16 years to unfold. Clearly, this antithetical view proposes that some energy transitions can occur much more quickly than commonly believed.

Which side is right? Similar to other controversies in the energy studies literature (Sovacool et al. 2016); this paper holds that both are right. After presenting evidence in support of both theses, it elucidates a common ground consisting of four arguments. First, sometimes the 'speed' or 'scale' at which an energy transition occurs has less to do with what actually happened and more to do 
with what or when one counts. Second, what may seem a sweeping transition can actually be a bundle of more discrete minor conversions or substitutions. Third, energy transitions are complex, and irreducible to a single cause, factor, or blueprint. Fourth, most energy transitions have been, and will likely continue to be, path dependent rather than revolutionary, cumulative rather than fully substitutive.

\section{One side: Energy transitions are long, protracted affairs}

This view holds energy transitions-defined by some as the time that elapses between the introduction of a new fuel or technology (sometimes called a 'prime mover') and its rise to 25 per cent of national market share-takes a significant amount of time (Smil 2010a). The Global Energy Assessment (GEA) (2012: 788), a major international, interdisciplinary effort to understand energy systems better, notes that 'transformations in energy systems' are 'long-term change processes' on the scale of decades or even centuries. This view holds that, as two Stanford University scientists write, 'it appears that there is no quick fix; energy system transitions are intrinsically slow' (Myhrvold and Caldeira 2012: 1). Support for this side comes from (1) the historical record, (2) the validity of looking at the 'big picture', and (3) the literature on 'lock-in' and 'path dependency'.

\subsection{History shows major transitions taking decades to centuries}

In the United States (US), crude oil took half a century from its exploratory stages in the 1860s to capturing 10 per cent of the global market in the 1910s, then 30 years more to reach 25 per cent. Natural gas took 70 years to rise from 1 per cent to 20 per cent. Coal needed 103 years to account for only 5 per cent of total energy consumed in the US and an additional 26 years to reach 25 per cent (Smil 2012). Nuclear electricity took 38 years to reach a 20 per cent share, which occurred in 1995.

Globally, we see even longer timeframes involved with energy transitions. Coal surpassed the 25 per cent mark in 1871, more than 500 years after the first commercial coalmines were developed in England. Crude oil surpassed the same mark in 1953; about nine decades after Edwin Drake drilled the first commercial well in Titusville, Pennsylvania, in 1859. Hydroelectricity, natural gas, nuclear power, and 'other' sources such as wind turbines and solar panels still have yet to surpass the 25 per cent threshold - as Figure 1 depicts_-with only nuclear reaching the meagre 5 percent mark. 
Figure 1: Major transitional shifts in global energy supply, 1750-2015

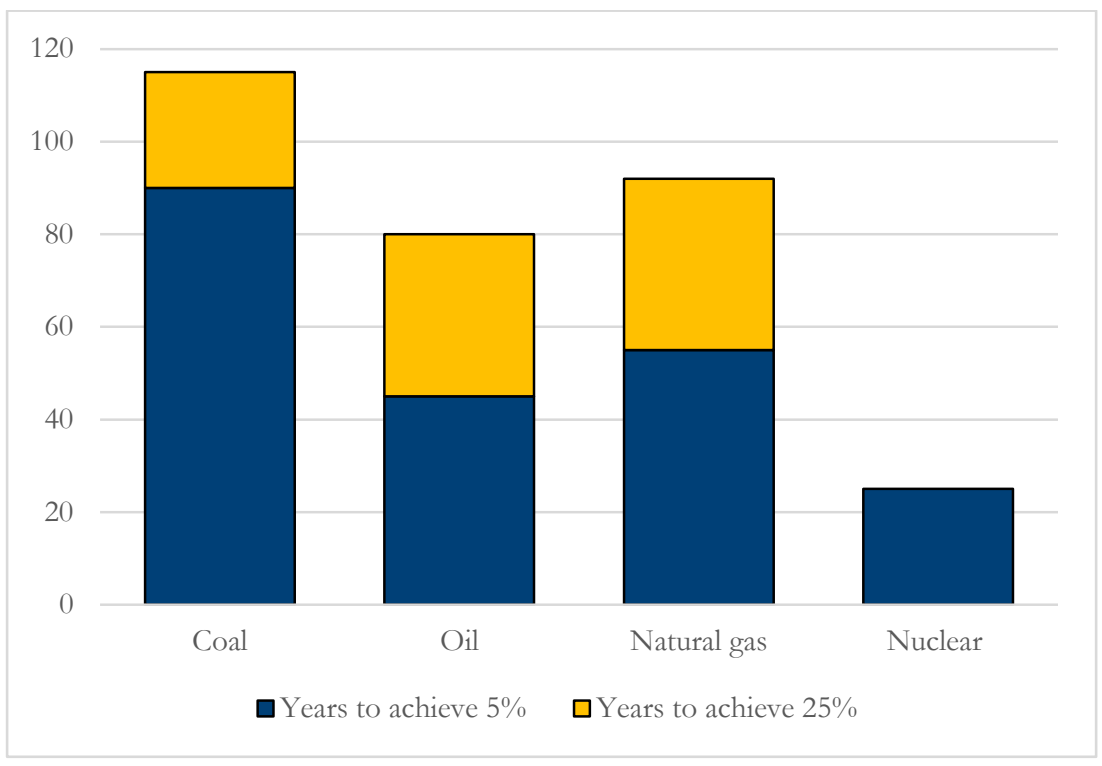

Source: author's illustration based on Smil (2012).

Assessing prime movers rather than fuels, Smil (2010b) adds that steam engines were designed in the 1770s, but didn't take off until the 1800s, and the gasoline powered internal combustion engine, first deployed by Benz, Maybach, and Daimler in the middle of the 1880s, reached widespread acceptance in the US only in the 1920s, even later for Europe and Japan. As Smil (2012: 3) deduces from these examples:

Energy transitions have been, and will continue to be, inherently prolonged affairs, particularly so in large nations whose high levels of per capita energy use and whose massive and expensive infrastructures make it impossible to greatly accelerate their progress even if we were to resort to some highly effective interventions.

This is why he calls energy systems 'a slow-maturing resource' and jokes that 'energy sources, they grow up so ... slowly' (Smil 2012: 2-3). As he remarks, 'it is impossible to displace [the world's fossil-fuel-based energy] super-system in a decade or two-or five, for that matter. Replacing it with an equally extensive and reliable alternative based on renewable energy flows is a task that will require decades of expensive commitment. It is the work of generations of engineers' (Smil 2012: 3).

The notion that energy transitions are inherently lengthy events finds further support from energy analysts Peter Lund and Roger Fouquet. Lund (2006) found that market penetration of new energy systems or technologies can take as long 70 years. Short 'take-over times' of less than 25 years are limited to a few end-use technologies such as water heaters or refrigerators, and are not common for major infrastructural systems like those involving electricity or transport. A second study of Lund's (2010a: 650) exploring 'how fast new energy technologies could be introduced on a large scale' estimated that the earliest wind could produce more than 25 per cent of world electricity, and solar 15 per cent, would be 2050 - 40 years from the date of his study. As Lund (2006: 3318) noted, 'the inertia of energy systems against changes is large, among others because of the long investment cycles of energy infrastructures or production plants' and the 'rate of adoption of these new [renewable energy] technologies would not exceed that of oil or nuclear in the past' (Lund 2010b: 3580). Analogously, Fouquet (2010) studied various transitions between both energy fuels and energy services from 1500 to 1920, and found that, on average, 
each single transition has an innovation phase exceeding 100 years followed by a diffusion phase approaching 50 years.

\subsection{Analysts need to focus on the 'big picture'}

Furthermore, proponents of this view argue that one must look at the big picture. That is, the absolute change in energy systems, rather than discrete growth within a particular market, and the overall impact on society.

For instance, an energy system can grow rapidly, in an absolute sense, but still fail to grow in a comparative sense. Hydroelectricity in the US was a low-cost source of energy in the 1950s and 1960s, where it grew in capacity threefold from 1949 to 1964. However, during this time, because other sources of energy (and demand for electricity) grew faster, hydropower's overall national share dropped from 32 per cent to 16 per cent (O’Connor 2010). Similarly, from 2000 to 2010, global annual investment in solar PV increased by a factor of 16, investment in wind grew fourfold, investment in solar heating threefold. This sounds impressive-yet the overall contribution of solar (heating and PV) and wind to total final energy consumption grew from less than one-tenth of one per cent to slightly less than one per cent over the same period (Sovacool 2016), hardly a drop in the bucket.

Furthermore, part of a big picture approach means realizing that energy transitions do not always produce desirable results. The massive energy transitions that occurred in Japan from 19181945, North Korea in the 1990s, and Cuba in the 1990s saw societies grapple with sudden shifts in the availability of energy. Japan lost upwards of 70 per cent of its oil imports due to the US trade embargo of 1941, North Korea dropped 90 per cent of their oil imports from the Soviet Union in 1991, and Cuba saw a decline of energy imports from the Soviet Union of 71 per cent between 1989 and 1993. In each case, national planners responded to energy scarcity with military force (Japan) or by preserving the privileges of the elite at the expense of ordinary people (North Korea and Cuba) (Friedrichs 2013).

\section{3 'Path dependency' and 'lock-in' make future transitions difficult}

A final thread of this thesis is that desirable energy transitions are so difficult to achieve because of the momentum, path dependency, or obduracy of the existing system exerts on actors. In the case of energy systems, large sums of labour, capital, and effort are 'sunk' into them that they create their own 'inertia' (Knox-Hayes 2012; Steinhilber et al. 2013). On top of that, institutional legacies protect the status quo, and political regulations, tax codes, and even banks and educational institutions come to support a particular energy pathway, along with associated coalitions (Goldthau and Sovacool 2012). The result is that energy transitions, breaking out of these embedded systems, require a 'long-term transformation' that is 'a messy, conflictual, and highly disjointed process' (Meadowcroft 2009). Collectively, these technological and behavioural forces 'lock' us into a carbon dependent energy system that highly resists change (Unruh 2000). In the case of prime movers, we see similar resistance. As Smil (2010: 140) writes, 'There is often inertial reliance on a machine that may be less efficient (steam engine, gasoline-fueled engine) than a newer machine but whose marketing and servicing are well established and whose performance quirks and weaknesses are known. The concern is that rapid adoption of a superior converter may bring unexpected problems and setbacks.'

In order to counteract this inertia, scholars looking at energy transitions have argued that truly 'transformative change' must be the result of alterations at every level of the system, simultaneously. That is, one must alter technologies, political and legal regulations, economies of scale and price signals, and social attitudes and values together, making transition a gruelling 
process. Or to use parlance from sociotechnical systems theory, it is rare that innovation niches become regimes and rarer still for those regimes to influence the broader, global landscape (Geels and Schot 2007; Schot and Geels 2008). This parallels what feminist scholar, Eve Kosofsky Sedgwick (1993) termed, the 'Christmas Effect' to describe the way that institutions, technology, and behaviour can coalesce around a common goal. During the holidays, the institutions of Western society come together and speak 'with one voice' for the Christmas holiday. Christian churches build nativity scenes and hold a greater number of masses; state and federal governments establish school and national holidays; the media 'rev up the Christmas frenzy' and 'bark out the Christmas countdown' (Sedgwick 1993). Such socio-technical inertia favouring the Christmas holiday exerts profound and lasting influence over our behaviour, and the argument runs that a similar alignment of values and incentives occurs with energy. This could be why in their forecasts about the future; the US EIA (2013) still predicted in 2013 that in 2040, three-quarters of energy in the US would come from oil, coal, and natural gas. The International Energy Agency (2012: 51) similarly projected that in 2035, under their 'Current Policies' scenario, 80 per cent of total primary energy supply worldwide would come from 'traditional' fossil fuels.

\section{The other side: Energy transitions can happen quickly}

Contrary to those emphasizing the longevity of energy transitions, an alternate view is that under certain conditions (or, if one chooses to count different things), energy transformations can occur rather speedily. Arguments in support of rapid transitions hold that (1) we have seen numerous fast transitions in terms of energy end-use, (2) plentiful examples of national-scale transitions litter the historical record, and (3) we can sufficiently learn from these trends so that favourable future energy transitions can be expedited. This section of the paper explores no less than ten 'quick' energy transitions, five of them focussed on end-use devices such as lighting and air conditioning, five of them focussed on national systems such as oil in Kuwait and nuclear power in France. Table 1 provides an overview of these cases, which collectively involved almost a billion people.

Table 1: Overview of rapid energy transitions

\begin{tabular}{|c|c|c|c|c|}
\hline Country & Technology/Fuel & $\begin{array}{l}\text { Period of } \\
\text { Transition }\end{array}$ & $\begin{array}{l}\text { Number of Years from } \\
1 \text { to } 25 \text { per cent market } \\
\text { share }\end{array}$ & $\begin{array}{l}\text { Approximate Size } \\
\text { (population affected in } \\
\text { millions of people) }\end{array}$ \\
\hline Sweden & $\begin{array}{l}\text { Energy-efficient } \\
\text { ballasts }\end{array}$ & $1991-2000$ & 7 & 2.3 \\
\hline China & Improved cookstoves & 1983-1998 & 8 & 592 \\
\hline Indonesia & $\begin{array}{l}\text { Liquefied petroleum } \\
\text { gas stoves }\end{array}$ & 2007-2010 & 3 & 216 \\
\hline Brazil & Flex-fuel vehicles & 2004-2009 & 1 & 2 \\
\hline United States & Air conditioning & $1947-1970$ & 16 & 52.8 \\
\hline Kuwait & Crude oil & 1946-1955 & 2 & 0.28 \\
\hline Netherlands & Natural gas & $1959-1971$ & 10 & 11.5 \\
\hline France & Nuclear electricity & 1974-1982 & 11 & 72.8 \\
\hline Denmark & $\begin{array}{l}\text { Combined heat and } \\
\text { power }\end{array}$ & $1976-1981$ & 3 & 5.1 \\
\hline $\begin{array}{l}\text { Canada } \\
\text { (Ontario) }^{*}\end{array}$ & Coal & $2003-2014$ & 11 & 13 \\
\hline
\end{tabular}

Note: * The Ontario case study is the inverse, showing how quickly a province went from 25 per cent coal generation to zero.

Source: Author's compilation. 


\subsection{History shows speedy transitions in energy end-use devices}

At least five transitions in end-use devices, or prime movers, have occurred with remarkable rapidity: lighting in Sweden, cookstoves in China, liquefied petroleum gas stoves in Indonesia, ethanol vehicles in Brazil, and air conditioning in the US.

Sweden was able to phase in an almost complete shift to energy efficient lighting in commercial buildings in about nine years (Lund 2007). Swedish Energy Authorities arranged for the procurement of high-frequency electronic ballasts for lights in office buildings, commercial enterprises, schools, and hospitals, which saved 30 to 70 per cent compared to ordinary ballasts, in 1991. They used a multi-pronged approach of standardization and quality assurance, direct procurement, stakeholder involvement, and demonstrations to disseminate those ballasts. They began by collaborating with experts to develop a list of lighting quality factors for commercial buildings, and then asked for competitive tenders from manufacturers that met these standards. Then, the government directly purchased almost 30,000 units in a pilot phase, and worked with real estate management companies (for new buildings) and owners of public, commercial, and industrial buildings (for retrofits) to ensure that they were installed (Ottossen and Stillesjo 1996). After the pilot phase, they promoted distribution through government subsidies, sponsored demonstrations of the technology among the commercial sector, and involved consumer groups in discounted bulk purchases. Due to these concerted efforts, self-supporting volume effects were reached as early as 1996, catalysing very rapid market penetration, which jumped from about 10 per cent that year to almost 70 per cent by 2000. In essence, this meant that between 1991 and 2000, 2.3 million Swedish workers experienced changes in the lights at their offices.

The Chinese Ministry of Agriculture managed an even more impressive National Improved Stove Programme (NISP), managed by the Bureau of Environmental Protection and Energy (BEPE), from 1983 to 1998 (Smith et al. 1993; Brown and Sovacool 2011a). The BEPE adopted a 'self-building, self-managing, self-using' policy focussed on having rural people themselves invent, distribute, and care for energy-efficient cookstoves, and it set up pilot programmes in hundreds of rural provinces. From the start of the programme until 1998, the NISP was responsible for the installation of 185 million improved cookstoves and facilitated the penetration of improved stoves from less than one per cent of the Chinese market in 1982 to more than 80 per cent by 1998-reaching half a billion people, as Table 2 shows. The cookstoves being installed in China in 1994, during the height of the programme, were equivalent to 90 per cent of all improved stoves installed globally. As a consequence, Chinese energy use per capita declined in rural areas at an annual rate of savings of 5.6 per cent from 1983 to 1990. 
Table 2: Households adopting improved stoves under the Chinese NISP and affiliated provincial programmes

\begin{tabular}{lllll}
\hline & $\begin{array}{l}\text { NISP Households } \\
\text { (million) }\end{array}$ & $\begin{array}{l}\text { Households under } \\
\text { Provincial } \\
\text { Programmes (million) }\end{array}$ & $\begin{array}{l}\text { Total Households / } \\
\text { year (million) }\end{array}$ & $\begin{array}{l}\text { Total People / year } \\
\text { (million) }\end{array}$ \\
1983 & 2.6 & 4.0 & 6.6 & 21.1 \\
1984 & 11 & 9.7 & 20.7 & 66.2 \\
1985 & 8.4 & 9.5 & 17.9 & 57.3 \\
1986 & 9.9 & 8.5 & 18.4 & 58.9 \\
1987 & 8.9 & 9.1 & 18 & 57.6 \\
1988 & 10 & 7.5 & 17.5 & 56 \\
1989 & 4.5 & 5 & 9.5 & 30.4 \\
1990 & 3.6 & 7.8 & 11.4 & 36.5 \\
$1991-1998$ & 7.8 & 57.2 & 65 & 208 \\
Total & 66.7 & 118.3 & 185 & 592 \\
\hline
\end{tabular}

Source: author, based on Brown and Sovacool (2011a).

Indonesia also ran a large rural energy household programme focussing on the conversion from kerosene stoves to liquefied petroleum gas (LPG) stoves to improve air quality. Under leadership from their Vice President Jusuf Kalla, the Indonesian 'LPG Megaproject' offered households the right to receive a free 'initial package' consisting of a 3 kilogram LPG cylinder, a first free gas-fill, one burner stove, a hose, and a regulator. The government, in tandem, lowered kerosene subsidies (increasing its price) and constructed new refrigerated LPG terminals to act as national distribution hubs. Amazingly, in just 3 years-from 2007 to 2009-the number of LPG stoves nationwide jumped from a mere 3 million to 43.3 million, meaning they served almost two-thirds of Indonesia's 65 million households (or about 216 million people). Six entire provinces, including that of Jakarta, the capital, were declared 'closed and dry'; meaning that the programme reached all of its targets, and that all kerosene subsidies were withdrawn (Budya and Arofat 2011).

Brazil has perhaps the fastest energy transition on record, though (to be fair) it depends on what one counts. Brazil created its Proálcool programme in November 1975 to increase ethanol production and substitute ethanol for petroleum in conventional vehicles, and in 1981, six years later, 90 per cent of all new vehicles sold in Brazil could run on ethanol-an impressive feat. However, a more recent transition, connected in part to the Proálcool programme, is even more noteworthy. The Brazilian government started incentivizing flex-fuel vehicles (FFVs) in 2003 through reduced tax rates and fuel taxes. These Brazilian FFVs were capable of running on any blend of ethanol from zero to 100 per cent, giving drivers the option of switching between various blends of gasoline and ethanol depending on price and convenience. The first year FFVs entered the market in 2004, they accounted for 17 per cent of new car sales but they rapidly jumped to 90 per cent in 2009-meaning 2 million FFVs were purchased in total over the first five years of the programme (Brown and Sovacool 2011b).

Air conditioning in the US is a final example. In 1947, mass-produced, low-cost window air conditioners became possible, enabling many people to enjoy air conditioning without the need to buy a new home or completely renovate their heating system (National Academy of Engineering 2013). That year, only 43,000 units were sold, but by 1953, the number had jumped to one million, as air conditioners became endorsed by builders eager to mass produce 
affordable, yet desirable, modern homes and electric utilities that wanted to increase electricity consumption throughout the growing suburbs (Rosen 2011). Consequently, more than 12 per cent of people (occupying 6.5 million housing units) reported to the US Census in 1960 that they owned an air conditioner, rising to 25 per cent in 1963, and 35.8 per cent in 1970, representing 24.2 million homes and more than 50 million people (US Census Bureau 1960, 1970). Since then, the presence of air conditioning in single-family homes jumped from 49 per cent in 1973 to 87 per cent in 2009 (US EIA 2011). In hot and humid places such as Southern Florida, its use grew from 5 per cent in 1950 to 95 per cent in 1990. American motorists also use 7 to 10 billion gallons of gas annually to air condition their cars. In aggregate, the US on an annual basis now consumes more electricity for air conditioning than the entire continent of Africa consumes for all electricity uses (Cox 2012). Or, in other terms, the US currently utilizes more energy (about 185 billion $\mathrm{kWh}$ ) for air-conditioning than all other countries' air conditioning usage combined (Sivak 2013).

\subsection{Fast transitions in national energy supply have occurred}

Proponents of this alternative view also point to five other transitions that have occurred at the national level: to crude oil in Kuwait, natural gas in the Netherlands, nuclear electricity in France, combined heat and power in Denmark, and coal retirements in Ontario, Canada.

Two concurrent modifications, in electricity and transport, catalysed an almost complete shift in Kuwait's national energy profile in about 9 years. Oil use catapulted from constituting a negligible amount of total national energy supply in 1946 to 25 per cent in 1947 and more than 90 per cent in 1950 (Kuwait Ministry of Planning 1988). In 1938, when Kuwait was still a small, impoverished British protectorate, geologists discovered the Burgan oilfield, which proved to be the world's second largest accumulation of oil following Saudi Arabia's Ghawar oil field. Commercial exploitation began in earnest (after a suspension of operations due to World War II) in 1946, increasing from 5.9 million barrels that year to 16.2 million barrels in 1947, and 398.5 million barrels in 1955, in tandem with the development of other oil fields (Al-Marafie 1989). Within five years-1945 to 1949—-the Kuwaiti oil industry was transformed from one dependent on five gallon barrels being distributed manually to customers, carried on camels, donkeys, or wooden push carts to one characterized by huge volumes and scale economies that were dependent on motorized trucks and tankers, pipelines, and filling stations. Simultaneously, Kuwait began using oil for electricity generation. The Kuwait Oil Company obtained and commissioned its first $500 \mathrm{~kW}$ generator in 1951 and in 1952, built a $2.25 \mathrm{MW}$ Steam Power Station at Al-Shewaikh, essentially tripling national electricity capacity in three years. Demand for such electricity grew considerably, doubling again by 1960, and then increasing (in per capita terms) from 1,473 kWh to 9,255 kWh in 1985 (Al-Marafie 1988). Thereafter a rapid expansion of distillation units, refineries, petrol stations, and the establishment of the Kuwait National Petroleum Company in 1960, the same year Kuwait helped form the Organization of Petroleum Exporting Countries, saw oil's rise continue so that in 1965, Kuwait became the world's fourth largest producer of oil (behind the US, USSR, and Venezuela, and ahead of Saudi Arabia). As even energy transition sceptic Smil (2010b: 55) concedes, 'In energy terms Kuwait thus moved from a pre-modern society dependent on imports of wood, charcoal, and kerosene to an oil superpower in a single generation'.

The Netherlands - thanks in large part to the discovery of a giant Groningen natural gas field in 1959-started a rapid transition away from oil and coal to natural gas (Smil 2010b). That year, coal supplied about 55 per cent of Dutch primary energy supply followed by crude oil at 43 per cent and natural gas less than 2 per cent. In December 1965, however, one year after gas deliveries began from Groningen, natural gas supplied 5 per cent of the Netherland's primary energy, rising quickly to 50 per cent by 1971, an ascent visually depicted in Figure 2 . To facilitate 
the transition, the government decided in December 1965 to abandon all coal mining in the Limburg province within a decade, doing away with some 75,000 mining-related jobs impacting more than 200,000 people. What made the transition successful was that the government strategically implemented countermeasures such as subsidies for new industries, the relocation of government industries from the capital to regions of the country hardest hit by the mine closures, retraining programmes for miners, and offering shares in Groningen to Staatsmijnen (the state mining company). After its peak output in the mid-1970s, extraction of gas at Groningen was purposely, scaled back to maximize the lifetime of the field, though natural gas continued to play a prominent role in the nation's energy mix. In 2010, for instance, natural gas still provided 45 per cent of total primary energy supply, larger than any other source (EC 2010).

Figure 2: Coal, natural gas, and oil supply in the Netherlands, 1950 to 2010

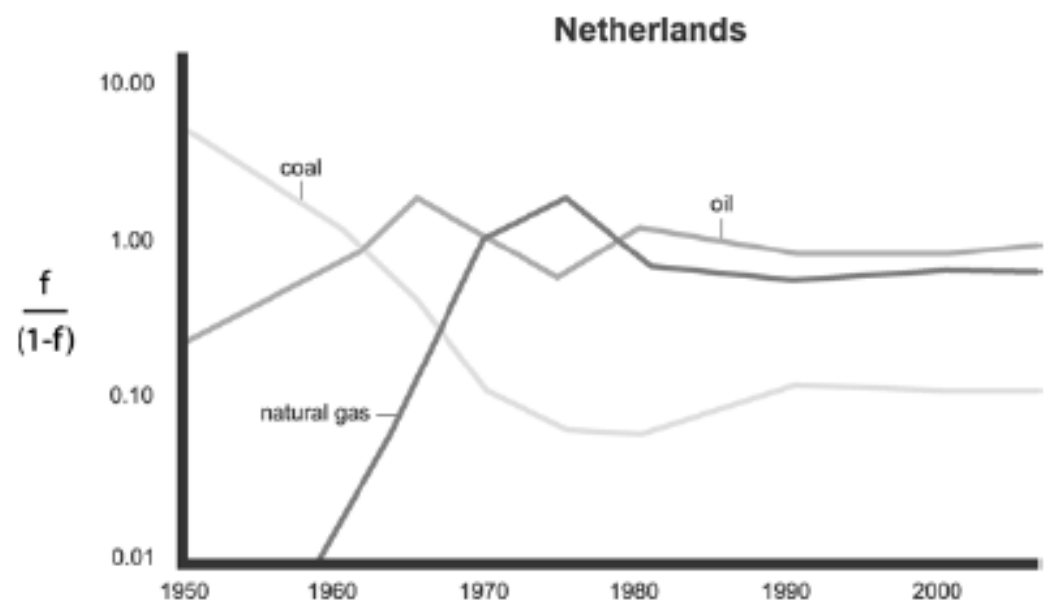

Source: author, based on Smil (2010a).

The French transition to nuclear power was also swift. Following the oil crisis in 1974, Prime Minister Pierre Messmer announced a large nuclear power programme intended to generate all of France's electricity from nuclear reactors to displace the Republic's heavy dependence on imported oil. As the maxim went at the time, 'No coal, no oil, no gas, no choice!' The 'Messmer Plan' proposed the construction of 80 nuclear power plants by 1985 and 170 plants by 2000 . Work commenced on three plants-Tricastin, Gravelines, and Dampierre-immediately following the announcement of the plan and France ended up constructing 56 reactors from 1974 to 1989 . As a result, nuclear power grew from 4 per cent of national electricity supply in 1970 to 10 per cent in 1978 and almost 40 per cent by 1982 (Araujo 2013). As Grubler (2010: 5186) has noted, 'the reasons for this success lay in a unique institutional setting allowing centralized decision-making, regulatory stability, dedicated efforts for standardized reactor designs and a powerful nationalized utility, EDF, whose substantial in-house engineering resources enabled it to act as principal and agent of reactor construction simultaneously'.

Though Denmark is perhaps more famous for a transition to wind energy, a far more accelerated transition occurred in the 1970s and 1980s. This transition, also in the electricity sector, was away from oil-fired electricity to other fossil fuels and Combined Heat and Power (CHP) plants. From 1955 to 1974, almost all heating in Denmark was provided by fuel oil, which meant the oil crisis had particularly painful impacts on the country's economy (Sovacool 2013). The Danish Energy Policy of 1976 therefore articulated the short-term goal of reducing oil dependence, and it stated the importance of building a 'diversified supply system' and meeting two-thirds of total heat consumption with 'collective heat supply' by 2002. Moreover, it sought to reduce oil dependence 
to 20 per cent, an ambitious goal that involved the conversion of 800,000 individual oil boilers from natural gas and coal. In a mere five years-from 1976 to 1981-Danish electricity production changed from 90 per cent oil-based to 95 per cent coal-based. Stipulations in favour of CHP were further strengthened by the 1979 Heat Supply Act, whose purpose was to 'promote the best national economic use of energy for heated buildings and supplying them with hot water and to reduce the country's dependence on mineral oil' (Sovacool 2013: 833). As a result, CHP production increased from trivial amounts in 1970 to supply 61 per cent of national electricity and 77 per cent of the country's district heating in 2010.

A final example is intriguing because rather than transitioning towards something it involves transitioning away. In 2003, the government of Ontario committed to retiring all coal-fired electricity generation by 2007 , something they accomplished a few years behind schedule. Ontario's oldest coal plant, the 1,140 MW Lakeview facility, was closed in April 2005 followed by sequential closures of Thunder Bay (306 MW), Atikokan (211 MW), Lambton (1,972 MW), and Nanticoke (3,945 MW) from 2007 to 2014. Coal generation thus declined from 25 per cent of provincial supply in 2003 to 15 per cent in 2008, 3 per cent in 2011, and zero in 2014, as Figure 3 illustrates. The primary justification for the closure, apart from its obvious climate change benefits, was public health. A government study estimated that shifting away from coal would reduce some 333,660 related illnesses and more than 700 deaths related to coal pollution to fewer than 6 deaths and only 2,460 illnesses. Put into monetary terms, the 'coal switch' was estimated to save US $\$ 4.4$ billion per year in health, environmental, and financial damages along with US\$95 million in displaced operating and maintenance costs (Office of the Premier 2013). To achieve this transition, Ontario invested more than US $\$ 21$ billion in cleaner sources of energy including wind, hydroelectricity, solar, and nuclear power, as well as US\$11 billion in transmission and distribution upgrades (Toronto Ministry of Energy 2013). Ontario is on track to see renewable sources of electricity grow to 46 per cent of supply by 2025 , and typical residential customers are expected to save US $\$ 520$ on their bills, and large industrial customers to save US $\$ 3$ million each on their bills, from 2013 to 2017.

Figure 3: Generation from coal in Ontario (in per cent) from 2003-14

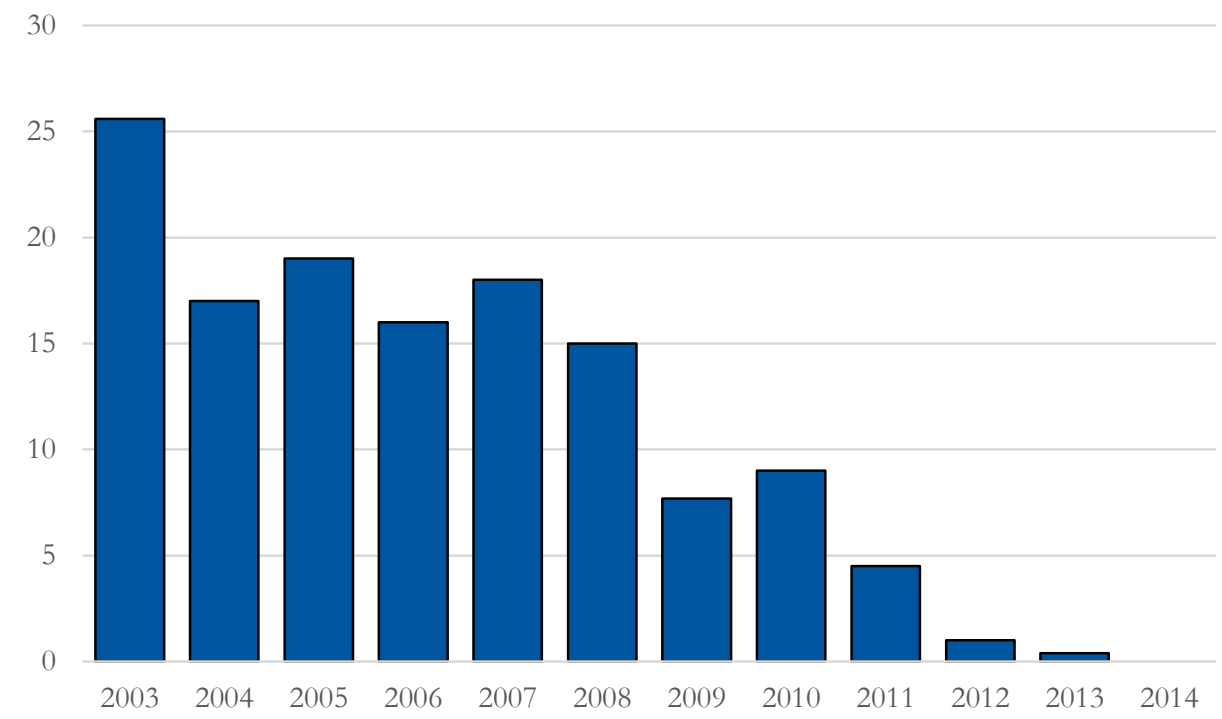

Source: author, based on the Office of the Premier (2013). 


\subsection{Future energy transitions can be expedited}

The final argument in favour of expeditious transition is that although some may have taken a great deal of time, we have learned a sufficient amount from them so that contemporary, or future, energy transitions can be expedited. As Araujo (2013:12) has argued:

Countries can, in fact, alter their energy balance in a significant way-stressing low carbon energy sources-in much less time than many decision-makers might imagine. Critical substitution shifts within [Brazil, France, Denmark, and Iceland] were accomplished often in less than 15 years. Moreover, these transitions were effectuated even amidst circumstances at times involving highly complex energy technologies.

Former Vice President Al Gore encapsulated this type of thinking when he argued, in 2008, that 'today I challenge our nation to commit to producing 100 percent of our electricity from renewable energy and truly clean carbon-free sources within 10 years' (Revkin 2008: 2). Gore went on to say that a complete change in energy production was 'achievable, affordable and transformative' within the course of one decade.

Therefore, it is possible that innovations in both technology and policy design can accelerate technological change, and achieve an energy transition, in ways not possible even just a few decades ago. Put another way, technological learning and innovation can result in new technologies and systems with the potential for exponential growth. Previous transitions such as that from wood to coal or coal to oil occurred without the accumulation of knowledge we have currently about the sociology, politics, and economics of energy transitions, i.e. without the complex historical analyses conducted by the likes of those such as Smil, Lund, and Fouquet arguing for caution. Because we now possess this knowledge, we can apply it going forward to minimize the unnecessary lag or delay of a future energy transition. Even Fouquet and Pearson (2012: 2) write that 'past energy transitions may not be the best analogies for a future low carbon energy transition'.

\section{Conclusions: Energy transitions are path dependent and cumulative}

How can these two almost incommensurable views be reconciled? This final part of the paper offers four synthetic conclusions.

First, sometimes the 'speed' or 'scale' at which an energy transition occurs has less to do with what actually happened and more to do with what or when one counts. The American transition to oil, according to Smil, took about 80 years to reach a 25 per cent share, yet during the most accelerated phase of that transition-from 1900 to 1925-oil grew from 2.4 per cent to 24 per cent, justifying those who would call it 'quick' (Pratt 1981). For air conditioning, whether one takes the time of first conception (Nikola Tesla developed electric motors that made possible the invention of oscillating fans in 1885), first invention (Willis Carrier invented the first modern system in 1902), or first successful commercial application (when Henry Galson developed an affordable mass produced system in 1947) greatly alters the perceived rate of market penetration (Oremus 2013). Brazil's transition to flex-fuel vehicles, arguably, took one year (from the start of the national programme to large-scale diffusion), more than twenty years (from the first invention of a FFV in 1980), almost thirty years (from the start of their national ethanol programme), or more than eight decades (from the first invention of a Brazilian engine capable of using ethanol in the 1920s). 
In the case of national transitions, we see similar ambiguity. Kuwait's transition to oil can be said to have begun in 1934, with the first concession given to the Kuwait Oil Company; or in 1937, when the first exploratory wells were drilled in the Burgan field; or in 1946, when commercial production began (the starting point we take); or even in 1949, when the first refinery was established. Similarly the French nuclear power programme could have defensibly begun in 1942 with the first chain reaction under the Manhattan project; or in 1945, with the formation of the Commissariat à l'Énergie Atomique; or in 1948, when their first research reactor was commissioned; or in 1974, with the launch of the Messmer Plan (or with the 1938 experiments by Lise Meitner and Otto Hahn, or even earlier!). Deciding what one counts includes within it normative assumptions about what an energy transition is; the problem is that most analysts do not make these assumptions transparent.

Second, what may seem a sweeping transition can actually be a bundle of more discrete conversions. As O'Connor (2010: 34) concludes, 'Big transitions are the sum of many small ones. Looking at overall energy consumption will miss the small-scale changes that are the foundation of the transitions'. This is because sometimes choices underlying technology adoption and fuel choice occur in technology-fuel bundles - shifts occurred to facilitate use of higher quality or more advanced forms of the same or substitute technology. For instance, the big ascent of oil discussed at the start of this paper, for example, can also be interpreted as a series of less grand changes involving:

- The switch from animal power to internal combustion engines for private vehicles, and the non-adoption of electric vehicles;

- The conversion of steam engines on ships and locomotives to diesel for marine vessels and trains;

- The shift from candles and kerosene for lighting to oil based lamps;

- The adaptation of coal boilers to oil boilers for the generation of electric power;

- The exchange of wooden fireplaces and coal stoves to oil and gas furnaces in homes.

Similarly, the air conditioning transition in the US was actually the result of concurrent innovations in air circulation, heat exchangers, heat pumps, halocarbon refrigerants, customization and mass production, and marketing (National Academy of Engineering 2013). It is often these 'minor transitions' that, when they occur in a concerted manner, create the 'major transitions' that are so easily identifiable.

Third, energy transitions are complex, and irreducible to a single cause, factor, or blueprint. They can be influenced by endogenous factors within a country, like aggressive planning from stakeholders in France (Messmer Plan), Denmark (regulations for district heating), Indonesia (a high level initiative backed by the Prime Minister's Office), or Ontario (city and municipal planners), accelerated by political will and stakeholder involvement, or exogenous factors outside of a country, such as military conflict (think of the World Wars spawning the French nuclear programme), a major energy accident (Chernobyl, Fukushima), or some global crisis (the oil shocks of the 1970s, the collapse of communism in the early 1990s). Other transitions, such as the adoption of air conditioning or ascendance of oil in Kuwait, were almost entirely market driven.

The implication is that, apart from transitions directly steered by strong policy programmes in choreographing the diffusion of technologies, most energy transitions have no magic formula. The United Kingdom, for instance, had the same access to natural gas that the Netherlands did, yet it was unable to cultivate the same type of changeover (Smil 2010b). The experience of tiny, affluent countries such as Denmark and Kuwait may be relevant for countries in a similar class 
(such as Belgium, Brunei, or Qatar), but less so for India or Nigeria. Moreover, the sociocultural or political conditions behind transitions in Brazil and China, at the time military dictatorships and communist regimes (respectively), are incompatible with the governance norms espoused in modern democracies across Europe and North America. Furthermore, history seems to suggest that past transitions - including many of the case studies presented here-are based on either discoveries of new, significant, and affordable forms of energy or technology, or scarcity conditions created by oil embargos or rapid political revolutions (Pratt 1981; Friedrichs 2013). Both abundance and scarcity have played, and will continue to play, an important role in future trajectories.

Fourth, and lastly, is that given these attributes of specificity, accretion, and complexity, most energy transitions have been, and will likely continue to be, path dependent rather than revolutionary, cumulative rather than fully substitutive. Older sources of energy-such as muscle power, animate power, wood power, and steam power-still remain in use throughout the world today; they have not entirely been replaced by fossil, nuclear, and modern renewable energy. One analyst at MIT recently commented that 'we'll use renewable energy more as technology makes it cheaper, but we're likely to keep using more of the other sources of energy, too' (Bullis 2013: 4). The motorized automobile behind (in part) the transition to oil in Kuwait and FFVs in Brazil is actually an amalgamation of earlier inventions fused together: the internal combustion engine, the wheel, the casting of steel, electric lights, tires, the assembly line, and so on. The CHP, geothermal, biomass, wind, and solar technology behind the transitions in Denmark, Iceland, and Ontario have benefitted from advances in the fossil-fuel chain including combined cycle turbines, batteries, and compressed air energy storage. Thus, transitions often appear not as an exponential line on a graph, but as a punctuated equilibrium, which dips and rises. To borrow from Strunz (2014), such dips and rises could even be interpreted as forms of highly nonlinear pathways, such as switching from on equilibrium to another.

Perhaps future energy transitions, because they can draw on these synergistic advances in multiple domains at once-cutting across materials, computing, combustion, gasification, nanotechnology, biological and genetic engineering, 3D printing and the industrial internet-can truly be accelerated in ways that past transitions have (generally) not been, even if it is the twin (and contradictory) factors of abundance and scarcity driving them. In addition, past interpretations of the pace of energy transitions, once reconciled, should affect how we view the prospects for conceiving and enabling a large-scale, low carbon energy transition on a global scale.

\section{References}

Al-Marafie, A.M.R. (1988). 'Assessment and prospects for energy resources in Kuwait'. Energy, 13(8): 647-56.

Al-Marafie, A.M.R. (1989). 'Assessment of oil and natural gas resources in Kuwait'. Energy, 14(1): $1-7$.

Araujo, K.M. (2013). 'Energy at the frontier: Low carbon energy system transitions and innovation in four prime mover countries'. PhD dissertation. Cambridge: MIT.

Brown, M.A., and B.K. Sovacool (2011a). 'China's national improved stove program, 19831998'. In M.A. Brown and B.K. Sovacool (eds), Climate Change and Global Energy Security: Technology and Policy Options. Cambridge: MIT Press, pp 292-301. 
Brown, M.A., and B.K. Sovacool (2011b). 'Brazil's proalcohol program and promotion of flexfuel vehicles'. In M.A. Brown and B.K. Sovacool (eds), Climate Change and Global Energy Security: Technology and Policy Options. Cambridge: MIT Press, pp 260-74.

Budya, H., and M.Y. Arofat (2011). 'Providing cleaner energy access in Indonesia through the megaproject of kerosene conversion to LPG'. Energy Policy, 39: 7575-86.

Bullis, K. (2013). 'How energy consumption has changed since 1776'. MIT Technology Review. Available at: http://www.technologyreview.com/view/516786/how-energy-consumptionhas-changed-since-1776/ (accessed 11 March 2016).

Cox, S. (2012). 'Climate risks heat up as world switches on to air conditioning'. The Guardian (Tuesday 10 July 2012).

European Commission (EC) (2010). 'Netherlands: Energy mix fact sheet'. Brussels: European Commission.

Fouquet, R. (2010). 'The slow search for solutions: Lessons from historical energy transitions by sector and service'. Energy Policy, 38(11): 6586-96.

Fouquet, R., and P.J.G. Pearson (2012). 'Past and prospective energy transitions: Insights from history'. Energy Policy, 50: 1-7.

Fri, R.W., and M.L. Savitz (2014). 'Rethinking energy innovation and social science'. Energy Research \& Social Science, 1: 183-7.

Friedrichs, J. (2013). The Future Is Not What It Used to Be: Climate Change and Energy Scarcity. Cambridge: MIT Press.

Global Energy Assessment (GEA) (2012). Global Energy Assessment - Toward a Sustainable Future. Cambridge, UK and New York: Cambridge University Press.

Geels, F.W., and J.W. Schot (2007). 'Typology of sociotechnical transition pathways'. Research Policy, 36: 399-417.

Giddens, A. (2009). The Politics of Climate Change. New York: Polity.

Goldthau, A., and B.K. Sovacool (2012). 'The uniqueness of the energy security, justice, and governance problem'. Energy Policy, 41: 232-40.

Grubler, A. (2010). 'The costs of the French nuclear scale-up: A case of negative learning by doing'. Energy Policy, 38: 5174-88.

Grubler, A. (2012). 'Energy transitions research insights and cautionary tales'. Energy Policy, 50: 818.

International Energy Agency (2012). World Energy Outlook. Paris: OECD.

Knox-Hayes, J. (2012). 'Negotiating climate legislation: Policy path dependence and coalition stabilization'. Regulation \& Governance, 6(4): 545-67.

Kuwait Ministry of Planning (1988). Statistical Review, 1950-1970 Kuwait City: Kuwait Ministry of Planning, Statistics and Census Sector.

Lund, P. (2006). 'Market penetration rates of new energy technologies'. Energy Policy, 34: 331726.

Lund, P. (2007). 'Effectiveness of policy measures in transforming the energy system'. Energy Policy, 35: 627-39.

Lund, P. (2010a). 'Exploring past energy changes and their implications for the pace of penetration of new energy technologies'. Energy, 35: 647-56. 
Lund, P. (2010b). 'Fast market penetration of energy technologies in retrospect with application to clean energy futures'. Applied Energy, 87: 3575-83.

Meadowcroft, J. (2009). 'What about the politics? Sustainable development, transition management, and long term energy transitions'. Policy Sciences, 42(4): 323-40.

Miller, C.A., A. Iles, and C.F. Jones (2013). 'The social dimensions of energy transitions'. Science as Culture, 22(2): 135-48.

Myhrvold, N.P., and K. Caldeira (2012). 'Greenhouse gases, climate change and the transition from coal to low-carbon electricity'. Environ. Res. Lett., 7014019.

National Academy of Engineering (2013). 'Air conditioning and refrigeration timeline'. Washington, DC: National Academies.

Nielsen, J.R., H. Hovmøller, P.-L. Blyth, and B. Sovacool (2015). 'Of "white crows" and "cash savers": A qualitative study of travel behavior and perceptions of ridesharing in Denmark'. Transportation Research, Part A 78: 113-23.

O’Connor, P.A. (2010). 'Energy transitions'. The Pardee Papers 12. . Boston: Boston University, The Frederick S. Pardee Center for the Study of the Longer-Range Future. Available at: https://www.bu.edu/pardee/files/2010/11/12-PP-Nov2010.pdf (accessed 11 March 2016).

Office of the Premier (2013). 'Ontario - First place in North America to end coal-fired power'. Available at: http://news.ontario.ca/opo/en/2013/11/ontario---first-place-in-northamerica-to-end-coal-fired-power.html (accessed 11 March 2016).

Oremus, W. (2013). 'A history of air conditioning'. Slate Magazine.

Ottossen, A., and S. Stillesjo (1996). 'Procurement and demonstration of lighting technologies for the efficient use of electricity'. Stockholm: Royal Institute of Technology and NUTEK.

Painuly, J.P. (2001). 'Barriers to renewable energy penetration: a framework for analysis'. Renewable Energy, 24: 73-89.

Pratt, J.A. (1981). 'The ascent of oil: the transition from coal to oil in early twentieth-century america'. In L.J. Perelman, A.W. Giebelhaus, and M.D. Yokel (eds), Energy Transitions: LongTerm Perspectives. Boulder, CO: AAAS, pp 9-34.

Revkin, A. (2008). 'The annotated gore energy speech'. New York Times, 17 July.

Riahi, K., F. Dentener, D. Gielen, A. Grubler, Z. Klimont, V. Krey, D.L. McCollum (2012). 'Energy pathways for sustainable development'. In T.B. Johansson, N. Nakicenovic, A. Patwardan, and L. Gomez-Echeveri (eds), Global Energy Assessment: Toward a More Sustainable Future. Cambridge, UK and New York: Cambridge University Press, pp 1203-306.

Rosen, R.A. (2011). 'Keepin' it cool: How the air conditioner made modern America'. The Atlantix, 14 July.

Schot, J.W., and F.W. Geels (2008). 'Strategic niche management and sustainable innovation journeys: theory, findings, research agenda, and policy'. Technology Analysis and Strategic Management, 20(5): 537-54.

Sedgwick, E.K. (1993). Tendencies. New York: Duke University Press.

Sivak, M. (2013). 'Will AC put a chill on the global energy supply?'. American Scientist.

Smil, V. (2010a). Energy Myths and Realities: Bringing Science to the Energy Policy Debate. Washington, DC: Rowman and Littlefield, pp 140-1.

Smil, V. (2010b). Energy Transitions: History, Requirements, Prospects. Santa Barbara, CA: Praegar. 
Smil, V. (2012). 'A skeptic looks at alternative energy'. IEEE Spectrum. Available at: http://spectrum.ieee.org/energy/renewables/a-skeptic-looks-at-alternative-energy (accessed 11 March 2016).

Smith, K.R., G. Shuhua, H. Kun, and Q. Daxiong (1993). 'One hundred million improved cookstoves in China: How was it done?'. World Development, 21(6): 941-61.

Sovacool, B.K. (2009). 'Rejecting renewables: The socio-technical impediments to renewable electricity in the United States'. Energy Policy, 37(11): 4500-13.

Sovacool, B.K. (2013). 'Energy policymaking in Denmark: Implications for global energy security and sustainability'. Energy Policy, 61: 829-41.

Sovacool, B.K. (2016). 'How long will it take? Conceptualizing the temporal dynamics of energy transitions'. Energy Research \& Social Science, 13: 202-15.

Sovacool, B.K., and R.F. Hirsh (2009). 'Beyond batteries: An examination of the benefits and barriers to plug-in hybrid electric vehicles (PHEVs) and a vehicle-to-grid (V2G) transition'. Energy Policy, 1095-103.

Sovacool, B.K., M.A. Brown, and S.V. Valentine (2016). Fact and Fiction in Global Energy Policy: Fifteen Contentious Questions. Baltimore, MD: Johns Hopkins University Press.

Steinhilber, S., P. Wells, and S. Thankappan (2013). 'Socio-technical inertia: Understanding the barriers to electric vehicles'. Energy Policy, 60: 5319.

Strunz, S. (2014). 'The German energy transition as a regime shift'. Ecol. Econ., 100: 150-8.

Toronto Ministry of Energy (2013). 'Achieving balance: Ontario's long-term energy plan'. Available at: http://www.energy.gov.on.ca/en/ltep/ (accessed 11 March 2016).

Unruh, G.C. (2000). 'Understanding carbon lock-in'. Energy Policy, 28: 817-30.

US Census Bureau (1960). US Census of Population and Housing 1960, Volume I. Washington, DC: United States Census Bureau.

US Census Bureau (1970). US Census of Housing 1970, Volume I. Washington, DC: United States Census Bureau.

US Energy Information Administration (EIA) (2011). 'Air conditioning in nearly 100 million U.S. homes'. Available at: http://www.eia.gov/consumption/residential/reports/2009/airconditioning.cfm (accessed 11 March 2016).

US Energy Information Administration (EIA) (2013). Annual Energy Outlook. Washington, DC: DOE. 